\title{
Collins sets out his vision for the $\mathrm{NIH}$
}

\section{BETHESDA, MARYLAND}

On his first day in the job, the new director of the US National Institutes of Health (NIH) laid out a five-point road map for the agency - which includes focusing greater attention on translational research, neglected diseases and health-care reform. But Francis Collins's top priority will be tackling budget constraints after the \$10.4-billion boost from the economic stimulus package runs out in 2010.

"I don't want you to think that all it's going to take is a few speeches or maybe a little playing the guitar for this to be successful," he said at a 17 August town-hall meeting at NIH headquarters in Bethesda.

For example, he estimated that only around 3\% of applicants for the stimulusbacked 'challenge grants' will be funded, although some have predicted success rates of below $1 \%$. Collins has raised red flags about losing a generation of young scientists if the NIH budget drops or flatlines. The budget for fiscal year 2010 has not yet been finalized, but the administration of President Barack Obama has requested

\section{a $1.4 \%$ increase over the 2009 budget of $\$ 30.6$ billion.}

Collins, who headed the National Human Genome Research Institute in Bethesda from 1993 to 2008 , made the case that investment in biomedical research creates jobs and offers quick economic returns. Looking ahead, he said that the agency should devote more money to "five areas of special opportunity". First, to applying high-throughput technologies in genomics and nanotechnology to discover the genetic bases of diseases including cancer, autism, diabetes and neurodegenerative disorders. Second, to developing diagnostics, preventative strategies and therapeutic tools through more public-private partnerships. Third, to reining in the costs of health care with comparative-effectiveness research and personalized medicine. Fourth, to expanding research into diseases affecting the developing world. Finally, to increasing budgets and investing in training and peer review to achieve a predictable funding trajectory for the research community.

"He presented a vision that was very much tailored to the times - scientifically and in terms of our public-health challenges, of where the nation is now, and where the mission of the NIH lies ahead," says Raynard Kington, who has served as acting director since last October and will return to his role of deputy director.

Collins stressed that he plans to devote all his energy to his new position, although he will maintain an active research lab. His latest book (on personalized medicine) is slated for a January 2010 release, he said, and he has resigned from the Washington DC-based BioLogos Foundation, an organization he founded earlier this year aimed at bridging the gap between science and religion. "I don't want anyone at NIH or outside of NIH to think that I have a religious agenda in coming to this role," said Collins, a devout Christian. "I will not. I'm here as your scientific director and I will keep that focus."

However, Collins's wife, genetic counsellor Diane Baker, will stay on the BioLogos board and will probably have a significant advisory role at the NIH, he said.

Elie Dolgin

\section{Environmental concerns delay seismic testing}

\section{An environmental lawsuit is} threatening the departure of a longplanned, US\$4.7-million research cruise to image sea-floor structures off the coast of western Canada.

The RV Marcus Langseth, a vessel operated by Columbia University in New York for the US National Science Foundation, had acquired all its permits to depart on 21 August for the Endeavour hydrothermal vents, 250 kilometres southwest of Vancouver Island. But on 10 August, the Canadian activist legal group Ecojustice, in Vancouver, British Columbia, sued the university, the Canadian department of fisheries and oceans and the minister of foreign affairs, alleging among other things that proper procedures were not followed in assessing how the seismic air bursts set off during the cruise would affect marine life.

Cruise co-leader Douglas Toomey, a geophysicist at the

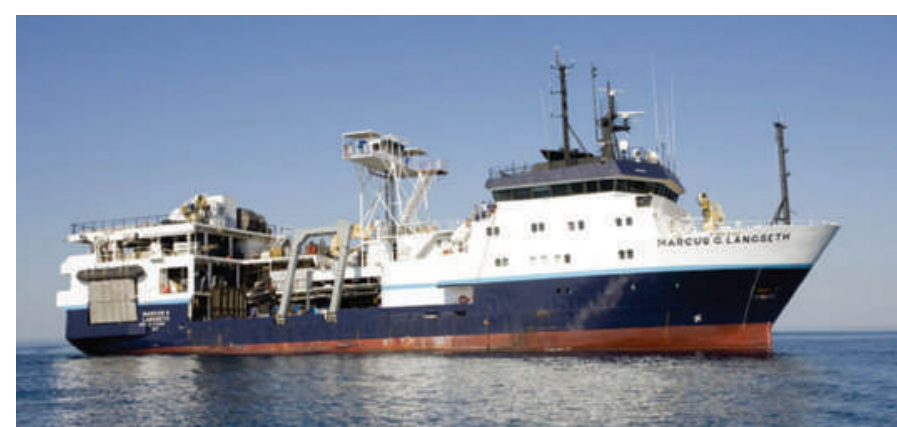

US research vessel Marcus Langseth was scheduled to work in Canadian waters.

University of Oregon in Eugene, says the ship was specifically scheduled and routed to avoid whales, and that marine-mammal observers would be on hand when airguns were fired.

As Nature went to press, a hearing on the lawsuit was being scheduled for this week.

The cruise plans to sink 64 portable seismometers near the Endeavour vent field, fire airguns into the water for 10 days, then retrieve the data-laden seismometers that pop to the surface. Toomey hopes that the analysis will answer important questions about the flow of Earth's mantle, as well as about earthquakes in the region.

Ecojustice officials didn't respond to interview requests, but a statement on its website attributed to group lawyer Lara Tessaro says that the Canadian government should "refuse to sanction the harassment of endangered whales". The lawsuit was filed on behalf of the Living Oceans Society and the Canadian Parks and Wilderness Society, and argues that the minister of foreign affairs should not grant the vessel clearance.

The use of airguns for seismic studies in western Canada has stirred environmental anger before. In 2008, a joint US-Canadian study of granite structures underlying British Columbia was halted (see Nature 451, 3; 2008). Since then, the region has seen growing environmental activism, including a recent sabotage (see Nature doi:10.1038/news.2009.715; 2009) of an onshore explosive charge that was part of a seismic test. Rex Dalton 